\title{
Terrestrial versus marine archives: biostratigraphical correlation of the Middle Pleistocene lacustrine records from central Europe and their equivalents in the deep-sea cores from the Portuguese margin
}

\author{
Krzysztof BIŃKA ${ }^{1, *}$ and Leszek MARKS ${ }^{2}$ \\ 1 University of Warsaw, Department of Palaeontology, Faculty of Geology, Żwirki i Wigury 93, 02-089 Warszawa, Poland \\ 2 University of Warsaw, Department of Climate Geology, Faculty of Geology, Żwirki i Wigury 93, 02-089 Warszawa, Poland
}

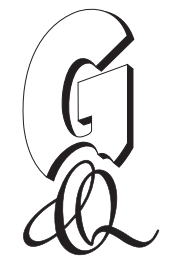

Bińka, K., Marks, L., 2018. Terrestrial versus marine archives: biostratigraphical correlation of the Middle Pleistocene lacustrine records from central Europe and their equivalents in the deep-sea cores from the Portuguese margin. Geological Quarterly, 62 (1): 69-80, doi: 10.7306/gq.1395

Associate Editor - Wojciech Granoszewski

The palaeolake from Ossówka, eastern Poland, is an unusual example of basin, in which sedimentation lasted from the beginning of the Holsteinian through several climatic oscillations until the Early Saalian, i.e. over a period of $\sim 70,000$ years. This provides us with the opportunity of correlating the dynamically changing events on land with their potential equivalents in the marine profiles. Alkenone-based temperature reconstructions using $U_{37}^{k^{\prime}}$ are an unusual tool in this respect. Nevertheless, as a result, we successfully relate this pollen sequence to the changing SST (sea surface temperature) values in the colder phases of MIS 11. The bipartite Ferdinandovian Interglacial was previously correlated with the upper part of the Cromerian complex (MIS 13 and MIS 15). Having at our disposal limits in the SST alkenone-based record, we clearly identify the stratigraphic position of the second warm phase of MIS 15 and a small fragment of MIS 14. In our opinion, the Rhume Interglacial, identified in Germany, should be located within MIS 13. Using the available orbitally tuned chronology, we also give a substantial input to estimate duration of these terrestrial interglacials, indicating the starting and ending points of their equivalents in the alkenone records.

Key words: Middle Pleistocene stratigraphy, MIS, duration of interglacial, terrestrial record, alkenone-based palaeotemperatures.

\section{INTRODUCTION}

Deep-sea cores are archives registering multiple sequences of climatic cycles deciphered using different techniques. Divided into marine isotope stages (MIS) of glacial and interglacial climate, the marine isotope stratigraphy provides the framework to which the Quaternary stratigraphers can refer their terrestrial profiles. However, we are often unable to correlate unequivocally these marine records with the pollen data on land. Until recently, only the stratigraphic positions of the MIS $5 e$ (Eemian Interglacial) and MIS 11c (Holsteinian Interglacial) equivalents were accepted on the continent (Desprat et al., 2005; Candy et al., 2014; Railsback et al., 2015; Berger et al., 2016) and the pollen sequences, which are the most powerful tool in the correlation, have well-defined palynological characteristics. Other terrestrial analogues of marine warm phases

\footnotetext{
* Corresponding author, e-mail: k.binka@uw.edu.pl

Received: April 8, 2017; accepted: November 3, 2017; first published online: January 8,2018
}

are known almost exclusively from mammalian or molluscan records or from pollen sequences that are mostly fragmentary and of uncertain position (Preusser et al., 2005). Yet even related to these two, accepted stratigraphic positions of interglacials (MIS 5e and MIS 11c) there exist some doubts. The position of the terrestrial equivalent of MIS $11 \mathrm{c}$ is questioned by some researchers (Bittmann and Müller, 1996; Zagwijn, 1998; Geyh and Müller, 2005, 2007; Kühl and Gobet, 2010). In turn, the identification of MIS 5e in central Europe can be also uncertain, because apart from well-recognized pollen records from the Central Massif in France (Reille et al., 2000), we have only poorly documented terrestrial analogues of MIS 7 and MIS 9 available in this region. These records, despite the differences, are very similar to the evolution of the Eemian vegetation.

Attempts were made to correlate not only the higher-rank MIS phases with their equivalents on continents, but also the intra-interglacial events or small-scale climate changes, 200-1000 years long. The well-defined Weichselian stratigraphy as well as older glacial/interglacial stratigraphic units (from MIS 10 to MIS 6) from the Central Massif and their precise correlation with the marine analogues using alkenone-based $\left(U_{37}^{k^{\prime}}\right)$ SST are the best example (Martrat et al., 2007). 
The aim of this paper is to propose reliable correlations between the terrestrial interglacials distinguished based on pollen records from eastern Poland and the marine stratigraphy, especially sea surface temperature records of the Iberian margin, covering the last 580 ky (Rodrigues et al., 2011). Such correlation is extremely important because of lack of reliable age control due to uncertainties of the applied dating techniques. In fact, stratigraphic setting of Middle Pleistocene interglacial pollen successions in Poland and especially of their post-interglacial parts is generally less or more uncertain. Therefore, the correlation between marine and terrestrial stratigraphic schemes based on independent age models seems to be the main challenge of the modern Quaternary stratigraphy.

Pollen records in marine sedimentary sequences are often the only source of information about the vegetation on the nearby land, allowing correlation with the environmental events registered in marine deposits. However, the quality of these pollen profiles is far from palynological standards required for these collected from lake deposits or peat-bogs. The results of examination of such sequences are usually of general nature, including tracing of interglacial successions with somewhat fluctuating boundaries, main components of the spectra, and percentage contents that are, however, quite different from those in the pollen rain on land. Certainly, no reliable conclu- sions should be drawn about smaller intra-interglacial and glacial oscillations, and the marine-derived pollen spectra cannot be the main base of conclusions on subtle decoupling trends between oceanic and land conditions. The reasons of these are multidimensional (see Sánchez Goñi et al., 1999, 2016; Oliveira et al., 2016, 2017). One is a long distance of a deep-sea core from the continent (Oliveira et al., 2016, 2017; Sánchez Goñi et al., 2016), which makes pollen that is best-adapted to long transport to be the main component of the spectrum. The problem of pollen transport has not been usually considered with adequate attention. The second problem is a low pollen concentration in the deposits and a low pollen sum counted if excluding Pinus equal from 100 to 166 per sample only (Oliveira et al., 2016). Application of Lycopodium tablets in order to calculate concentration of pollen in a definite volume was done by Desprat et al. (2005) (MD01-2447 core with the MIS 11 record), but their pollen sequence is not suitable to more subtle considerations. However, in this case, analysed interval is correlated by authors with the Holsteinian and three post-interglacial oscillations. Generally, the conclusions are based on the changing proportion of Quercus pollen.

The reinvestigation of the unique pollen succession from Ossówka, eastern Poland (Fig. 1), lasting 70 ky (Krupiński, 1995; Nitychoruk et al., 2005; Bińka and Nitychoruk, 2013),

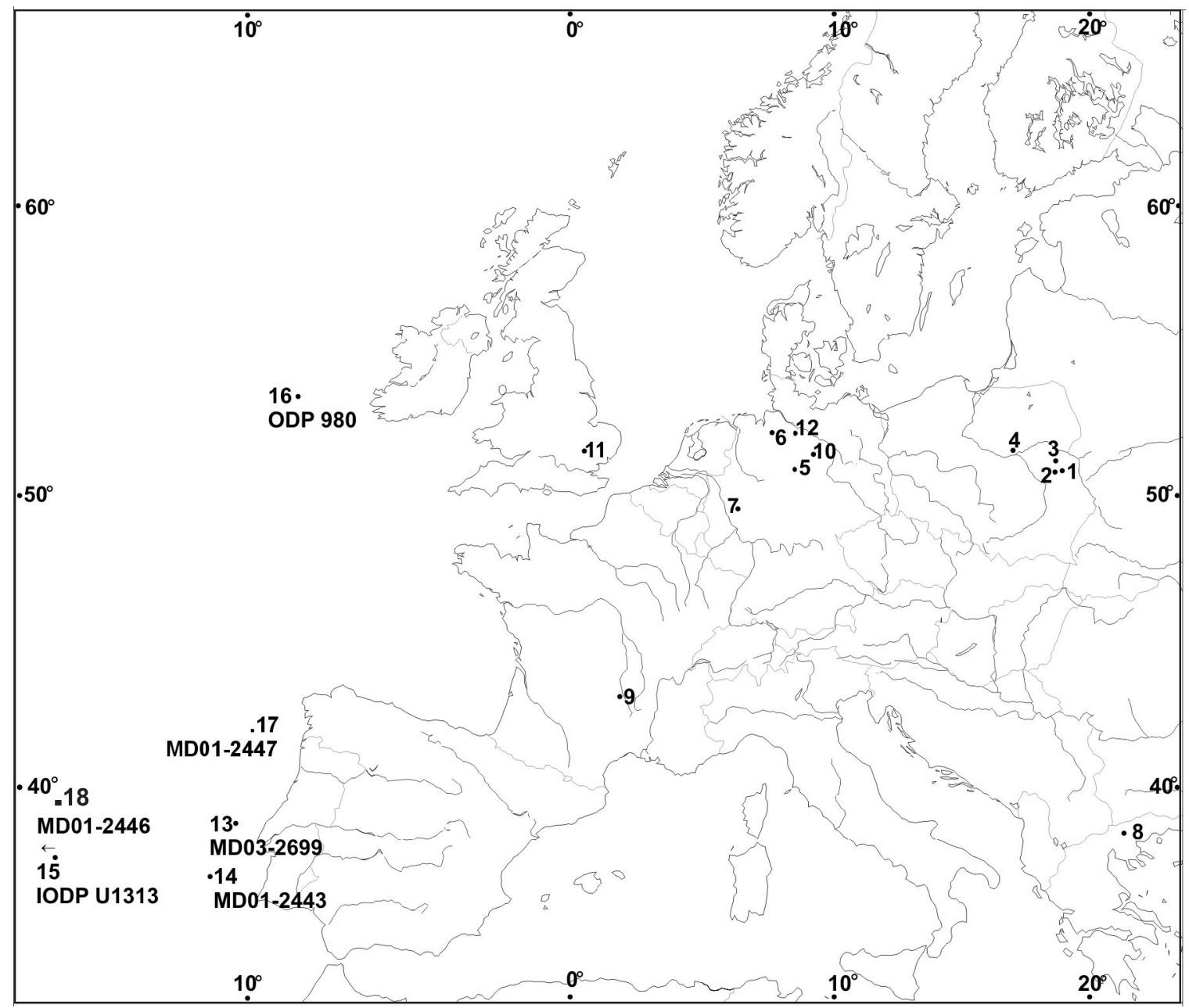

Fig. 1. Location of the discussed sites

1 - Ossówka, 2 - Łuków, 3 - Czaple, 4 - Błędowo, 5 - Bilshausen, 6 - Dethlingen, 7 - Döttingen, 8 - Tenaghi Philippon, 9 - Praclaux, 10 - Schöningen, 11 - Marks Tey, 12 - Munster-Breloh, 13 - MD03-2699, 14 - MD01-2443,

15 - IODP Site U1313, 16 - ODP Site 980, 17 - MD01-2447, 18 - MD01-2446 
gives a new impulse in this area of research. The sequence started in the Late Elsterian, continued throughout the Holsteinian, and terminated in the Saalian (Table 1). Numerous stadial/interstadial events with more subtle climate shifts are crucial for further considerations. The sequence from Łuków (Pidek and Poska, 2013), which is the second interesting pollen record reported from the nearby site, revealed a very complex succession with the two-phased Ferdinandovian Interglacial and a series of neighbouring stadials and interstadials. It has been usually correlated with MIS 15 (lower temperate part) and MIS 13 (upper one) or generally located in the upper segments of the Cromerian Complex (see Lindner et al., 2013).

Having high-resolution pollen profiles at our disposal, we test the possibility of correlating the marine records from the North Atlantic, especially $\delta^{18} \mathrm{O}$ of planktic/benthic foraminifera and alkenone-based $\left(\mathrm{U}_{37}^{k^{\prime}}\right)$ temperature reconstructions with pollen sequences on land.

The sites at Ossówka and Łuków, located in eastern Poland, and the nearest deep-sea cores are about a few thousand kilometres apart. However, also in this region, the influence of the North Atlantic Circulation (NAC) is predominant throughout a year, when the westerly winds bring moist air masses even much further eastwards than the analysed sites. On the other hand, polar continental air masses (westward displacement of the Siberian High) result in cold winters and warm summers. Hence, the influence of continental climate in eastern Poland is also an important factor. Because the surface waters at sites near Portugal "are derived in one form or another from the Gulf Stream and the North Atlantic Current (NAC)" (Voelker et al., 2010) the link between the climate in that area and this in Poland seems to be clear. As we can see from the Atlantic deep-sea cores, NAC influenced substantially the weather in western and central Europe in the middle and the Upper Pleistocene. Hence, the stratigraphical framework for the Quater- nary in these areas is generally similar, differing only in plant composition. Thus, it appears that the correlation of pollen records in eastern Poland is certainly possible.

\section{METHODS}

The sites at Ossówka and Łuków are located in eastern Poland at the latitudes of $52^{\circ} 11^{\prime} \mathrm{N}$ and $51^{\circ} 93^{\prime} \mathrm{N}$, respectively (Fig. 1). The Ossówka section reveals a continuous sequence of carbonate gyttja, laminated in the interglacial part and without any stratigraphical gaps (Krupiński, 1995; Nitychoruk, 2000). Quite recently, a new, $55 \mathrm{~m}$ long core from the central part of the palaeolake was analysed (Bińka and Nitychoruk, 2013). The site at Łuków, situated not far from Ossówka, is represented by a $10 \mathrm{~m}$ long sequence of lacustrine deposits.

Deep-sea records, selected for correlation procedures, are located at mid-latitudes and in the subpolar North Atlantic (Fig. 1). They represent different hydrologic conditions and productivity regimes: ODP Site 980 (the branch of NAC, subpolar regime), IODP Site U1313 (the branch of NAC, mid-latitude regime), core MD01-2447 offshore of the Iberian Margin (southward recirculation of NAC), cores MD03-2699 and MD01-2443 in nearshore positions on the Iberian Margin (subtropical Azores Current and upwelling) and ODP Sites 1056/1058 (Gulf Stream) (McManus et al., 1999; Martrat et al., 2007; Voelker et al., 2010; Rodrigues et al., 2011).

The correlation was performed with the peak by peak comparison. Efficiency of correlation depends on sampling resolution in the marine cores, e.g. in core MD03-2699 the $2 \mathrm{~cm}$ sampling interval allows an average resolution of 168 years (Rodrigues et al., 2011) and the temporal resolution for the MD01-2443 record does not exceed $250 \pm 149$ years for MIS 11 (Martrat et al., 2007). Because the length of the stadials/inter-

Quaternary stratigraphy of part of the Middle Pleistocene of Poland (after Lindner et al., 2013), and its correlation with the subdivisions from Western Europe

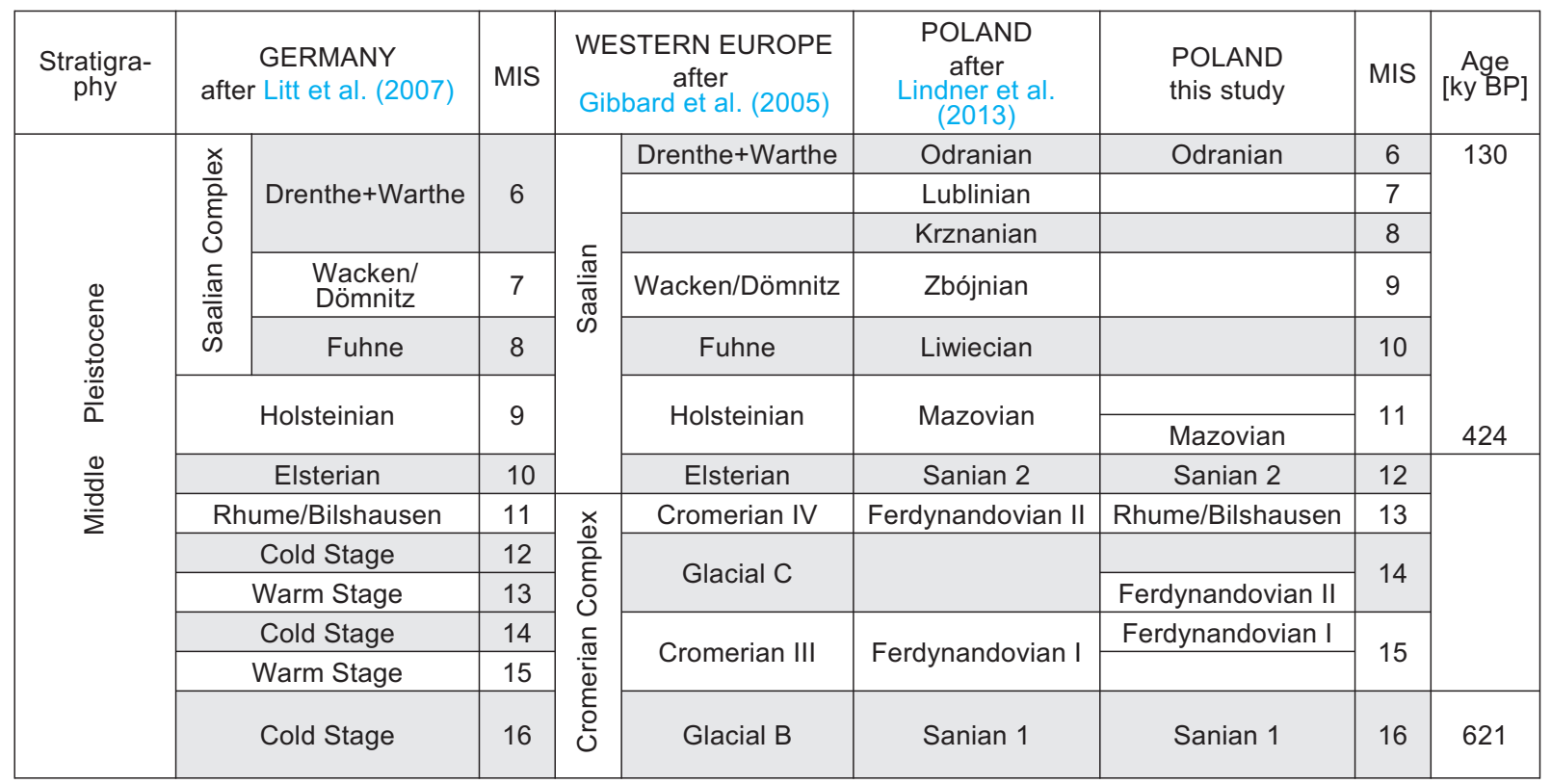

The position of the Holsteinian, Ferdinandovian and Rhume interglacials is given according to our study; glaciations and coolings are marked in grey 
stadials in the analysed pollen records exceeds significantly these estimations, the final correlation seems very likely.

The correlation is based upon the $\delta^{18} \mathrm{O}$ record of planktic/benthic foraminifera, which serves as an indicator in global ice volume and the alkenone-based temperature reconstruction $\left(\cup_{37}^{k^{\prime}}\right)$. In the latter case, the alkenone unsaturation in$\operatorname{dex}\left(U_{37}^{k^{\prime}}\right)$ is commonly converted into mean annual sea surface temperature (SST; e.g., Naafs et al., 2011). However, many factors, such as depth or seasonality of haptophyte blooms, can cause the index to deviate from the mean annual values and it should not be interpreted in a simplistic manner (Herbert, 2003). According to Lawrence et al. (2009), the estimates of alkenone temperature in the subpolar North Atlantic reflect probably summer conditions, because the highest productivity of coccolithophorids occurs from summer to early autumn in this area. Also, near the west coast of Portugal, blooms of coccoliths are observed first of all from spring to autumn and they are related to the intensity and persistence of upwelling (Silva et al., 2008; Amore et al., 2012). Because the core MD03-2699 is under the influence of the Portugal upwelling system, we can treat SST for this site as reflecting mostly the summer temperatures.

Stadials, interstadials and interglacial parts in pollen sequences with their reconstructed varying temperature range in the isotope and alkenone record should have their counterparts represented by maxima and minima of the curves (peak by peak comparison). Two basic plant communities in the pollen record from Ossówka and Łuków, which appear repeatedly in the examined sequences, comprise a pine forest (forming vegetation of the interstadials as well as of the onset and the end of the interglacials) and a tree-less steppe of stadials. Analogue positions of these have been identified in the alkenone or isotope records of a particular site and should represent more or less the same temperature on the chart.

\section{DISCUSSION}

In temperate Europe, the term interglacial, based on pollen analysis, represents a succession that started with birch/pine forest, followed by temperate deciduous forest and terminated with pine forest. Using this approach this term usually does not correspond with the marine/ice warm peaks described as odd numbers - MIS 5, 9, 11 (see review in Candy et al., 2014), because their duration is most often definitely shorter. Their equivalent in marine records is named "full interglacial condition" or "major warm climate peak", without precise identification of the onset and termination. These secondary peaks in marine isotope stages are named with additional numbers or letters (see Martinson et al., 1987; Railsback et al., 2015). Hence, locating these turning points on isotope curves allows calculating duration of the interglacial on the continent (see Sánchez Goñi et al., 1999).

The interval selected for correlation spans the terminal pine zone of the Holsteinian, and three pine interstadials (O-3, O-5 and O-7) and four steppe stadials dominated by Artemisia (O-2, O-4, O-6 and O-8) in the post-interglacial part (Fig. 2B). The first two interstadials represent a mature forest growing at higher temperatures than the third one. The O-4 stadial represents probably the short-term phase and the O-8 stadial is the longest one. Within these warm and cold stages, numerous minor oscillations were also observed. Each interstadial starts with a quick succession of juniper followed in the first two interstadials by birch forest with larch. Such forest represents partly post-fire vegetation as indicated by abundant Pteridium spores (Bińka and Nitychoruk, 2013). Scots pine forest is a climax community. A similar pattern was noted also at Praclaux in Central Massif, in the two long, reliable records of the Early Saalian (Reille et al., 2000) and at Schöningen in Germany (Urban et al., 1991; see Fig. 3).

Comprehensive studies of the pollen rain and the actual vegetation in southern Siberia (Pelánková and Chytrý, 2009) show that steppe communities occur in this region within the mean temperature range from $-20(-27)^{\circ} \mathrm{C}$ in January to 17 $(20)^{\circ} \mathrm{C}$ in July. Certainly, substage b of the $\mathrm{O}-8$ stadial is characterized by lower January temperatures than others, as indicated by a lower pollen concentration, higher NAP, and the decline of carbonate sedimentation. In southern Siberia, mature dry pine forests are limited by the mean temperature range from -19 to $-29^{\circ} \mathrm{C}$ in January and from 14 to $16^{\circ} \mathrm{C}$ in July. In turn, the pine forest in northern Finland, which may also serve as an analogue of interstadial communities, occurs from -14 to $-16^{\circ} \mathrm{C}$ in January and from 12 to $13^{\circ} \mathrm{C}$ in July (Kultti et al., 2006). Reconstruction of palaeotemperatures, based on post-fire vegetation and quick secessional initial phases, is rather impossible.

The age of the examined sequence results from the age of the underlying interglacial deposits. Typical succession of main plant components, the presence of two intra-interglacial climate oscillations: $\mathrm{OHO}$ and $\mathrm{YHO}$, indicative exotics, e.g. Pterocarya, and culmination of yew in the first half of the sequence prove its Holsteinian age (Bińka and Nitychoruk, 2013). We can find the same features in the successions in the Central Massif, Germany and Great Britain (Turner, 1970; Urban et al., 1991; Reille et al., 2000).

\section{MARINE RECORDS OF THE EARLY SAALIAN}

Numerous $\delta^{18} \mathrm{O}$ isotope records (planktic and benthic foraminifera) as well as alkenone-based SST reconstructions are the crucial instrument in correlation of marine events with those on land. Some of the records seem to be more valuable. These resulting from sophisticated stacking techniques show clear isotopic cold and warm stages, which generally suggest the presence of such glacial and interglacial stages on land. However, there are serious problems in correlation of smaller episodes, which are referred to as stadials/interstadials in continental Europe. Stacks composed of more than a single section do not eliminate, in fact, "noise" errors, but may cause that the real oscillation of lower amplitude is smoothed out as a side effect, e.g. in the SPECMAP project (Imbrie et al., 1984) and LR04 stack (Lisiecki and Raymo, 2005). The first one in the post-optimal interval of MIS 11 noted only a single interstadial, the second one indicated a smooth transition from a warm culmination to the glacial inception.

Continuous oscillation of the curves is a substantial problem in correlation of minor climatic events in the $\delta^{18} \mathrm{O}$ records, apart from the low-resolution sequences. In the case of stadial/interstadial units we cannot firmly evaluate their number or determine their climatic significance. The multispecies planktic $\delta^{18} \mathrm{O}$ isotope curves from core MD01-2443 (de Abreu et al., 2005) show so many variations in the discussed period that identification of clear trends is not possible. Similarly, in the IODP Site U1313 records (Stein et al., 2009; Voelker et al., $2010)$, both benthic and planktic $\delta^{18} O$ curves show a series of quick oscillations hard to correlate with those at Ossówka. Similar problems arise while analysing records from the core MD03-2669 and the ODP Sites 1056/1058 (Voelker et al., 2010).

There are only a few sites with clearly delimited minor events. In the ODP Site 980, the post-optimal part of MIS 11 is punctu- 


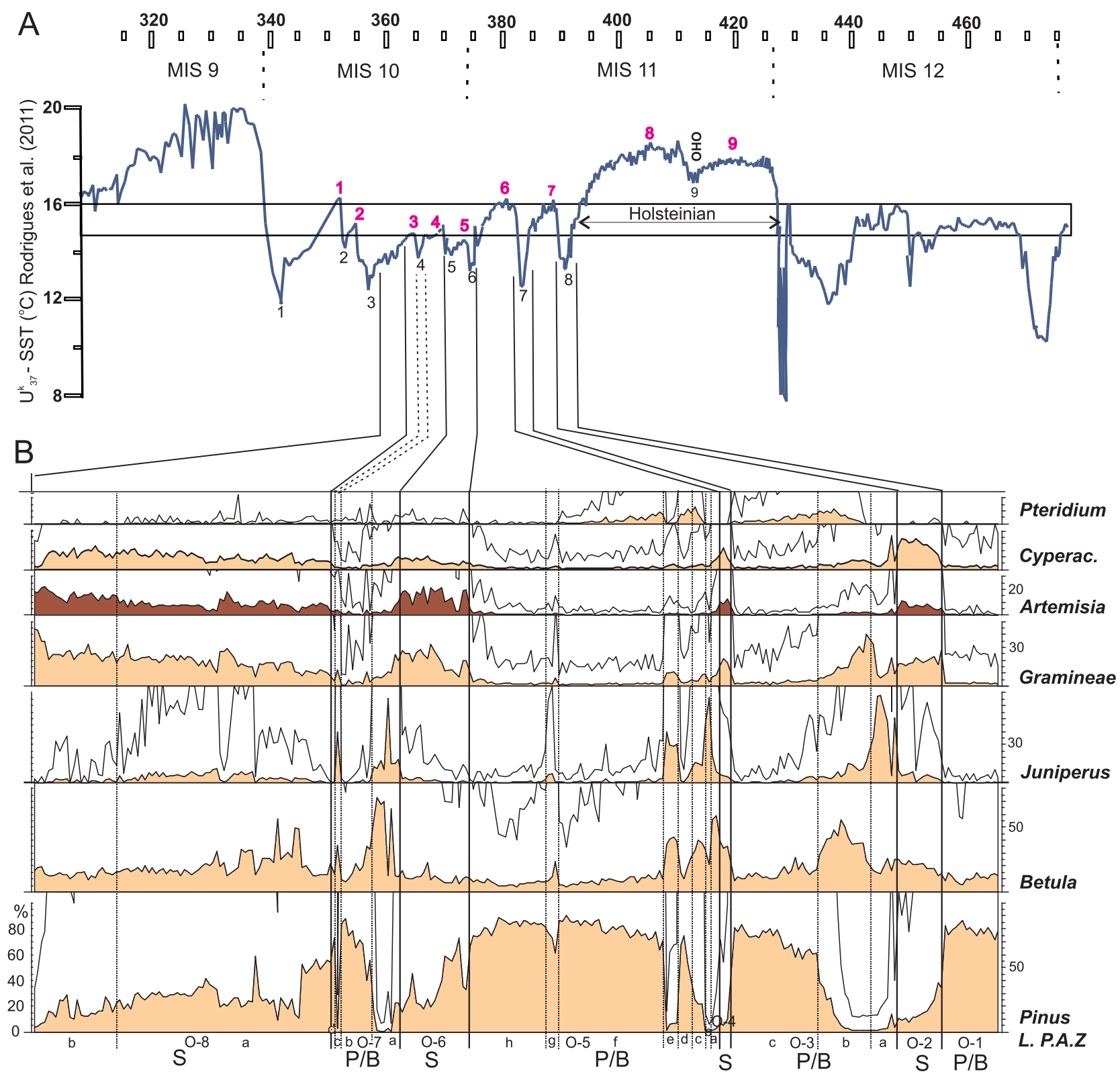

Fig. 2. Correlation of alkenone-based record $\left(U_{37}^{k^{\prime}}\right)$ of deep-sea core MD03-2699 (A - after Rodrigues et al., 2011) with the main pollen zones of the Holsteinian and Early Saalian sequence from Ossówka in eastern Poland (B - simplified pollen diagram after Bińka and Nitychoruk, 2013)

$\mathrm{OHO}$ - Older Holsteinian Oscillation; L PAZ - local pollen assemblage zone; interstadials in red and stadials in blue after Rodrigues et al. (2011). Elongated rectangle marks the temperature range corresponding with the pine forest in eastern Poland

ated by 2-4 undoubted interstadial episodes (McManus et al., 1999), whereas the MD01-2446 record reflects 3 post-interglacial warm and cold events with the descending trend of SST (Voelker et al., 2010). However, even in these cases, precise estimation of the SST level for stadials and interstadials is difficult.

Alkenone-based SST reconstructions $\left(\mathrm{U}_{37}^{k^{\prime}}\right)$ at the same sites provide, in our opinion, the most reliable data, recording even a short-lived climatic excursion. The high-resolution record of core MD03-2699 undoubtedly stands out among the few ones available (Voelker et al., 2010; Rodrigues et al., 2011). It is astounding that each stadial/interstadial phase in the Ossówka core has its close equivalent in the alkenone curve as regards both its relative magnitude and sedimentation rate (Fig. 2A).

During the first two interstadials, 6 and 7 on the curve of Rodrigues et al. (2011) and O-3 and O-5 at Ossówka, sea surface temperature increased to $15.8^{\circ} \mathrm{C}$. The end of interstadial 6 marks the onset of MIS 10. In the succeeding interstadial (bipartite interstadial 3-4 in MD03-2699 and 0-7 at Ossówka) the SST decreases to $\sim 14.5^{\circ} \mathrm{C}$. At Ossówka, the $0-7$ interstadial is also bipartite. However, we are treating this minor recurrence of colder conditions with birch and juniper as a single phase. The SST in the post-Holsteinian stadials varies from 13.3 to $14.1^{\circ} \mathrm{C}$ with rare, sharp downward shifts. Stadials 5 and 6 , separated by a small rise of SST (interstadial 5) as established by Rodrigues et al. (2011), can be the equivalent of the O-6 stadial at Ossówka.

At the MD01-2443 site, three interstadials are also noted after the full interglacial conditions (Martrat et al., 2007), two of which display the same SST $\left(\sim 17^{\circ} \mathrm{C}\right)$ and the third one is characterized by the lower SST $\left(14.5^{\circ} \mathrm{C}\right)$, a value equal to that from stadial 4 in MIS 10. This is incompatible with the pattern established for the succession at Ossówka. Similarly, in the MD01$2444 / 2443$ composite sequence (comprising four supercycles), 


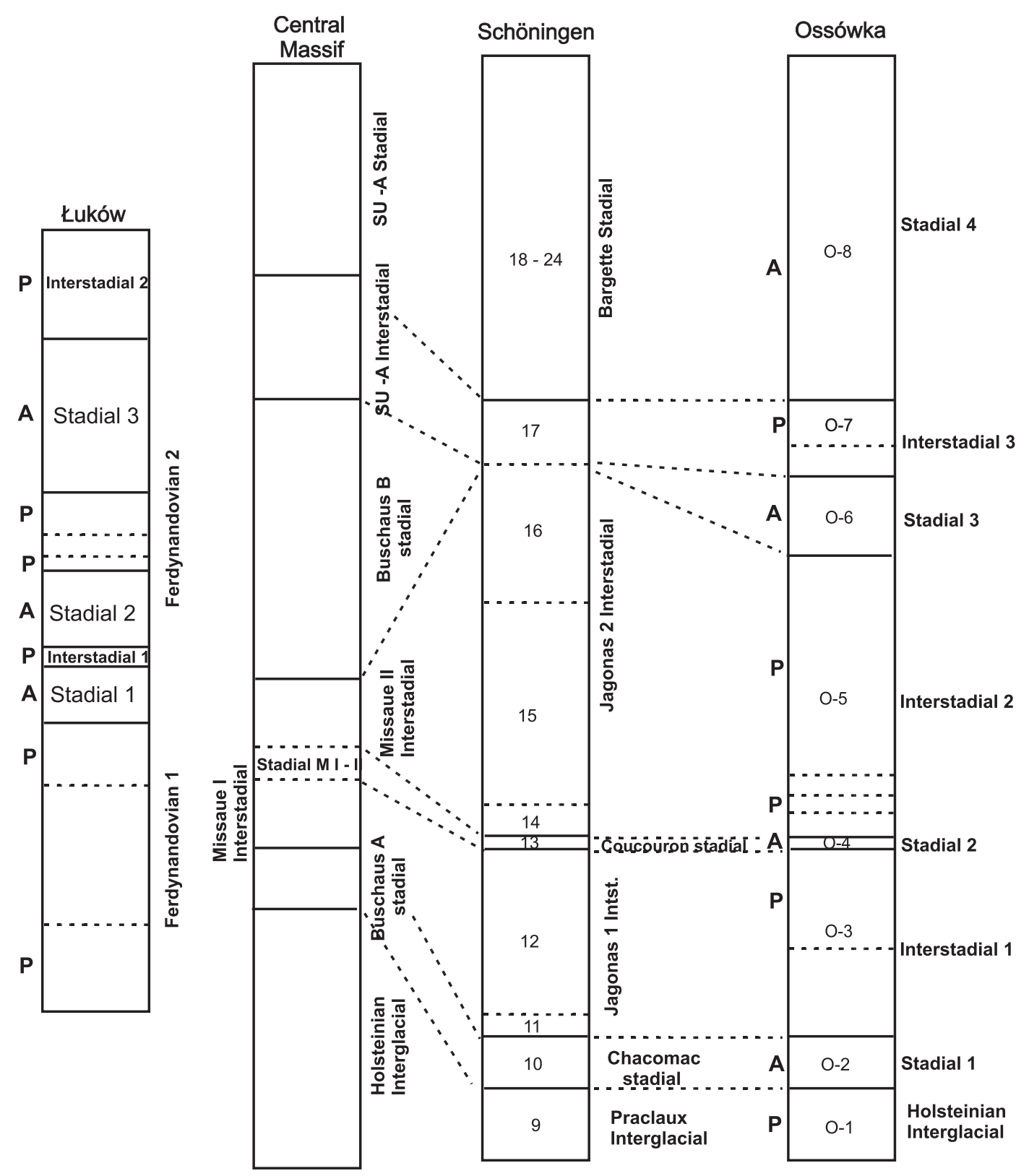

Fig. 3. Stratigraphy of the Ferdynandovian in the Łuków sequence and correlation between the Holsteinian/Early Saalian from Massif Central, Schöningen and Ossówka

A - Artemisia steppe, $\mathrm{P}$ - pine forest

$\mathrm{U}_{37}^{\mathrm{k}^{\prime}} \mathrm{SST}$ for the first two interstadials of the Weichselian (see Fig. 4) is almost the same as for the Holsteinian.

The IODP Site U1313 alkenone curve in the discussed interval shows three interstadials after a major warm peak, with relatively similar magnitude as at Ossówka, but it suffers from lower resolution (Stein et al., 2009). However, SST levels of the third one $\left(16^{\circ} \mathrm{C}\right)$ are in this case the same as the temperature of the stadial between the first and the second interstadial. The duration of some Early Saalian phases in the alkenone record is also quite different from those at Ossówka and in the core MD03-2699.

As regards the correlation power of alkenone records, the MD03-2699 site record, in which we can precisely find equivalents of all post-interglacial oscillations, is absolutely the best of these three ones. It is noteworthy that $\mathrm{OHO}$ is clearly marked in all three alkenone $\left(\cup_{37}^{k^{\prime}}\right)$ records (stadial 9; Rodrigues et al.,
2011), 14,000 years after the onset of the interglacial. In Europe, $\mathrm{OHO}$ is visible as a short-lived period of 350 years at Marks Tey (Turner, 1970) and 220 years at Dethlingen (Koutsodendris et al., 2010), indicated by a retreat of more demanding plants. In the pollen diagram from Kaliłów in eastern Poland (Bińka and Nitychoruk, 1996) we can see, however, that this event is an element of long-lasting climate deterioration, recorded by a gradual rise, culmination (with birch) and decrease of pine, indicating a decreased summer and winter temperatures and precipitation. It certainly lasted not less than 1500-2000 years. Such a pattern of gradual SST decrease and its absolute short minimum at $\sim 412$ ka (stadial 9; Rodrigues et al., 2011) is noted in the alkenone SST curves. This implies that the influence of the Atlantic circulation in eastern Poland diminished earlier and this cool trend lasted longer than the $\mathrm{OHO}$ at German sites. 


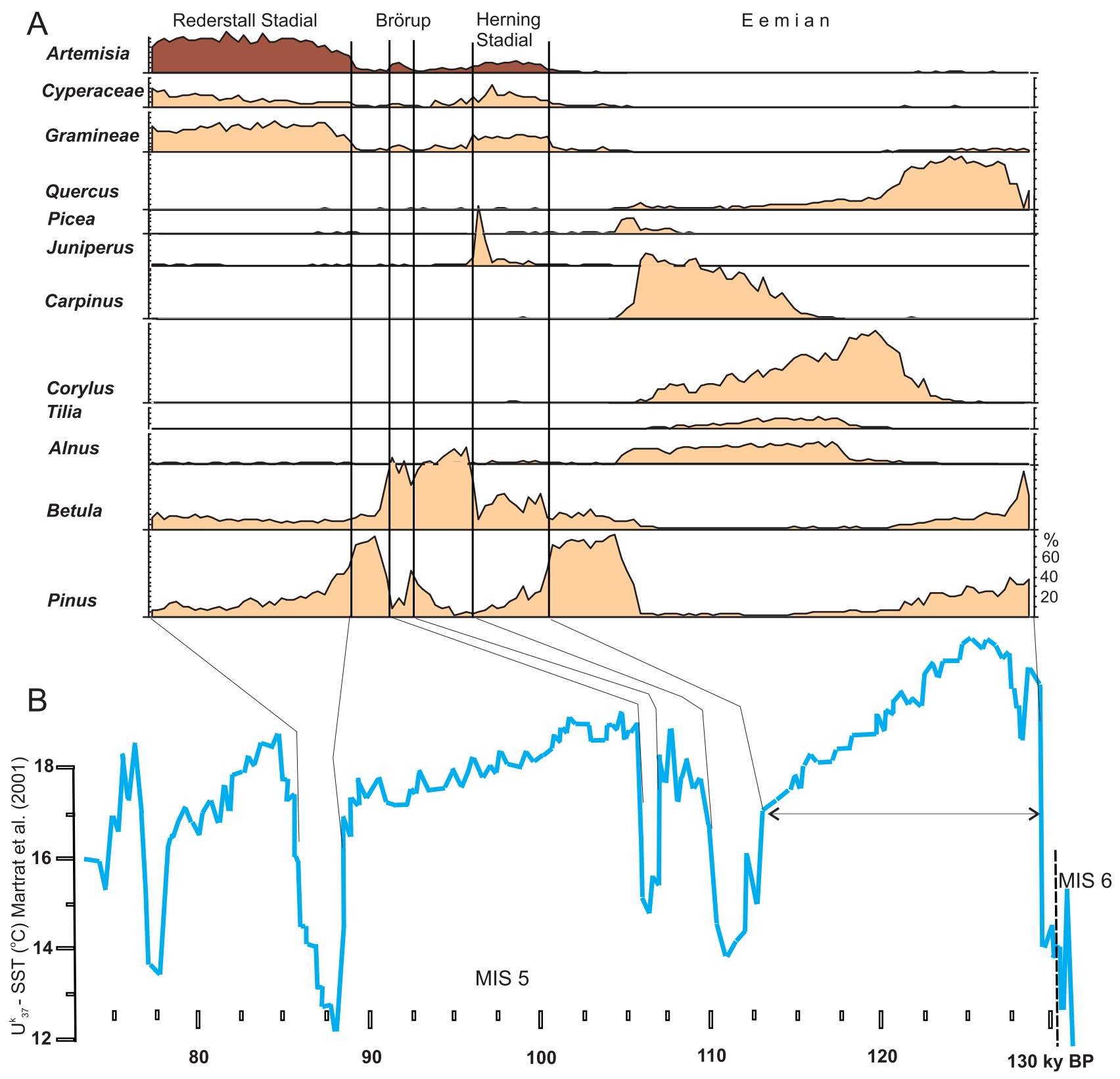

Fig. 4. Correlation of alkenone-based record $\left(U_{37}^{k^{\prime}}\right)$ of deep-sea core MD01-2444 (B - after Martrat et al., 2007) with the main stratigraphic units of the Eemian and Early Weichselian from Czaple, eastern Poland (A - simplified pollen diagram after Bińka and Nitychoruk, 2011)

For explanations see Figure 2

PRE-HOLSTEINIAN INTERGLACIAL IN THE ALKENONE RECORDS

A bipartite succession at Łuków starts with an initial birch/pine zone followed by a deciduous temperate forest, final pine forests of the first warm phase, two-phased steppe stadials with a short intervening pine interstadial, pine forest, temperate hornbeam forest, pine forest, long steppe period stadial, and finally by an interstadial with declining pine forest (Pidek and Poska, 2013). The Ferdynandovian Interglacial itself comprises only a part of the Łuków succession. It is represented only by two interglacial-rank warmings with the initial/final pine forests (Fig. 5).

In the stratigraphic schemes of both Poland and Western Europe, this interglacial is attributed to MIS 15 (older temperate stage) and MIS 13 (younger one) in the Cromerian Complex (Zagwijn, 1998; Lindner et al., 2013; Table 1). At Łuków, the estimated temperature range for pine forests is from -12 to $+15^{\circ} \mathrm{C}$, and for steppe vegetation from $-17^{\circ} \mathrm{C}$ and -10 to $+15^{\circ} \mathrm{C}$ (Pidek and Poska, 2013).

On the alkenone SST curve of Rodrigues et al. (2011) we use the boundary of $15.8^{\circ} \mathrm{C}$ for delimiting the presence of mature pine forests of the first two Saalian interstadials and of the onset/end of the Holsteinian. The area outlined above this limit (Fig. 2) shows the interglacial conditions with temperate vegetation. There can be some doubt that this bordering line delimits similar zones in other MIS periods. MIS 15, as suggested by deuterium and $\delta^{18} \mathrm{O}$ curves (Lisiecki and Raymo, 2005; Jouzel et al., 2007), is tripartite and divided by a long period of $\sim 30,000$ 
years with cooler conditions. The MD03-2699 alkenone record shows that the third culmination of MIS 15 (Fig. 5) and the short warm interval during MIS 14 are the only possible position for each of the nine pollen zones from Łuków, including minor separation of steppe by a pine episode. The whole Łuków sequence, in general, can be correlated with the second optimum of MIS 15, covering also almost completely MIS 14 (Fig. 5). Despite the fact that MIS 15 is represented by three warm segments visible in the LR04 stack, the two interglacial-rank warmings from Łuków cannot be coincidental with them, because such a long colder stage between them has not been confirmed in numerous Polish sequences. A characteristic feature of the second optimum is vegetation dominated by hornbeam, not by trees usually expanding at the beginning of the interglacial. Carpinus, Quercus and Betula represent ectomycorrhiza-dependent trees. Hornbeam occurs in the later stages of interglacials, when resources of the easily available phosphorous become lower (Kuneš et al., 2011). Once the temperate stages of the Ferdynandovian were separated by a 30,000 years long period of colder vegetation, the surface of the terrain would be refreshed as a result of geomorphologic processes and the ex- pansion of trees dependent on arbuscular myccorrhiza (early interglacial stages) would be quite likely. It is the additional argument for a relatively short time separating the two optima of this interglacial.

The SST profile from MD03-2699 shows that the pine forest at Łuków, like in the Early Saalian at Ossówka, existed under a similar range of SST, from 14.5 to $15.8^{\circ} \mathrm{C}$, and that the temperatures of the two optima were lower than those in the Holsteinian. Duration of the stratigraphic units at Łuków, expressed by the sedimentation rate, is similar to their equivalents in the alkenone record.

The Holsteinian and Ferdynandovian interglacials (irrespective of their internal dynamics), understood as the temperate successions from initial "birch/pine to the final pine", are of varying duration, as inferred from marine and laminated terrestrial records. In the marine sections, it is, however, not possible to indicate precisely the onset/ending point of "full interglacial conditions". Nevertheless, given that the SST level of $\sim 15.8^{\circ} \mathrm{C}$ in the MD03-2699 record is correlated with a pine forest of the final Holsteinian and the first two Saalian interstadials at Ossówka, we can estimate duration of both the marine "warm

A

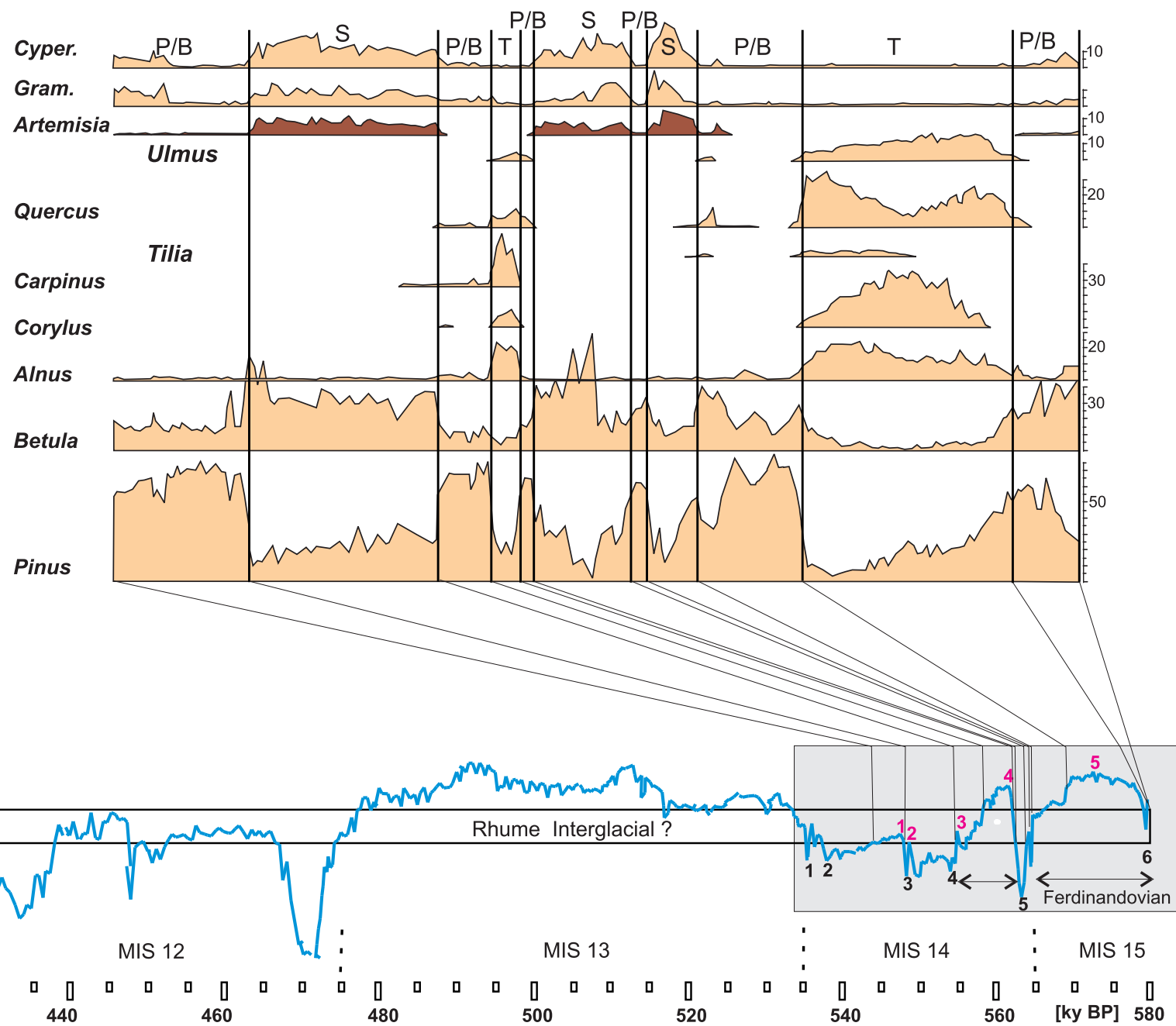

Fig. 5. Correlation of alkenone-based record $\left(U_{37}^{k^{\prime}}\right)$ of deep-sea core MD03-2699 (B - after Rodrigues et al., 2011) with the main pollen zones of the sequence from Łuków (A - simplified diagram, after Pidek and Poska, 2013)

P/B - pine/birch forest, S - steppe communities, T - temperate vegetation; interstadials (arabic numerals) in red and stadials in blue after Rodrigues et al. (2011). Elongated rectangle marks the temperature range corresponding with the pine forest in eastern Poland 
full interglacial conditions" and their analogue on land. It is worth-noting that the alkenone-based SST of $\sim 15.8^{\circ} \mathrm{C}$ in the MD03-2699 is characteristic also for the Allerød Interstadial (Rodrigues et al., 2011). At the Błedowo site (Bińka et al., 1991) a pine forest formed vegetational cover at that time too. Interglacial boundaries, thus outlined, allow estimating duration of the Holsteinian. The estimated age of 393-426 ka (33 ky) is very close to that at Ossówka. The duration of the Holsteinian $(\sim 25-30 \mathrm{ky})$ is accepted in most recent studies (see overview in Tzedakis et al., 2012; Candy et al., 2014). The first temperate optimum at Łuków, calculated "from pine to pine" and correlated with the third culmination of MIS 15, lasted $\sim 15 \mathrm{ky}$ (from 580 to 565 ka BP), while the upper hornbeam optimum with the bordering pine forests $-\sim 8 \mathrm{ky}$ (from 563 to $555 \mathrm{ka}$ ). Duration of the whole sequence from Łuków is therefore $\sim 40 \mathrm{ky}$. The bordering points marking interglacial conditions in the MD03-2699 SST record result in an extremely long duration of the interglacial period positioned with this approach within MIS13 - equal $57 \mathrm{ky}$ (from 536 to $478 \mathrm{ka} \mathrm{BP}$ ). Because the estimated age of the whole MIS 13 is $\sim 60$ ky (Rodrigues et al., 2011) this interglacial would comprise almost the entire isotope stage - an exceptional situation in comparison with other MIS. This warm stage imitates to some extent a climate change during the Holsteinian with the first phase colder than the second one (fir hornbeam zone) following the OHO (Voelker et al., 2010; Candy et al., 2014) as can be seen in marine and terrestrial records. However, temperature estimates of the first half of MIS 13 in the MD03-2699 core were similar or inconspicuously higher $\left(16-16.3^{\circ} \mathrm{C}\right)$ than these indicating the presence of a pine forest in eastern Poland. They were decidedly lower than the so-called first cold plateau of the Holsteinian, dominated in Poland by spruce, yew and alder. Duration of this very long boreal period is $\sim 18 \mathrm{ky}$. Later, we can observe in the alkenone SST record a long climatic optimum phase with SST of $17^{\circ} \mathrm{C}$, with two $18^{\circ} \mathrm{C}$ oscillations.

In Europe, the sequence of the Rhume Interglacial from Bilshausen (Luttig and Maarleveld, 1962; Müller, 1965) appears to correspond well to MIS 13. It is correlated with the Kärlich Interglacial and treated as an equivalent of MIS 11 or MIS 13 (Kühl and Gobet, 2010). It is also positioned between the Cromerian IV and the Holsteinian and correlated with the Ferdynandovian (Bittmann and Müller, 1992; Gaudzinski et al., 1996). Geyh and Müller (2005) treated the Rhume Interglacial as the counterpart of MIS 11 situated below the true Holsteinian (MIS 9). The sequence seems to be incomplete and in the pollen diagram there is a lack of initial zones, probably final ones and unidentified fragments of temperate intervals, probably removed during accumulation of sand layers. Laminated sediments indicate that this interglacial lasted $\sim 25$ ky (Kühl and Gobet, 2010) or 30 ky (Müller, 1965).

In the pollen diagram from Bilshausen, the first relatively stable period of pine - spruce forest with small admixture of temperate trees, $\sim 10 \mathrm{ky}$ long, resembles significantly the 'boreal' plateau of the first half of MIS 13 reflected in the MD03-2699 record, which lasted $\sim 18 \mathrm{ky}$. Below this sequence, Müller (1992) described laminated deposits, 8 ky long, which are hard to interpret without a renewed investigation with significantly higher resolution. It does not represent in our opinion three interstadials but a single long and cold interval. In the alkenone scheme (MD03-2699, Rodrigues et al., 2011), only an episodic interstadial with the SST at the "pine level" is noted (two samples) below MIS 13 in the corresponding period, which was probably too short to establish a forest at Bilshausen. The warm temperate period lasted $\sim 13$ ky at Bilshausen. This phase, like at Ossówka, is interrupted by the short-term "YHO-like" event, in which fir was almost completely removed from plant communities.

Different natures of the Holsteinian and the Rhume interglacials, despite their apparent resemblance including long duration, "YHO-like" episodic decline of fir and hornbeam, and a long period with a cool boreal forest in the first half, are indisputable. The differences are substantial with the occurrence of $\mathrm{OHO}$ noted in the European sections investigated with higher resolution, e.g. at Ossówka, Dethlingen (Koutsodendris et al., 2010, 2012) or Marks Tey (Turner, 1970). The late presence of Pterocarya is also diagnostic. In Poland, its pollen content is up to $10 \%$. The argument used by Candy et al. (2014) about location of the Holsteinian palaeolakes on the thick Anglian/Elsterian/Sanian 1 till, deposited by one of the greatest glaciations in Europe, is not without significance. In Poland, numerous Holsteinian lakes, often extensive, deep and with thick deposits, were also a result of this process. The commonly recognized early culmination of yew, e.g. in many sections of Poland, at Dethlingen and Munster-Breloh (Müller, 1974a), at Döttingen (Diehl and Sirocko, 2008) or in the Central Massif (Reille et al., 2000), marks probably a maximum sea level highstand in the warm part of MIS 11.

There is no doubt that fluctuations of SST in the MD03-2699 record between MIS 10 and MIS 15 are reflected by climate and vegetation changes in eastern Poland. Does it mean that climatic conditions off the Iberian Peninsula influenced weather in such remote areas? Today, the MD03-2699 site and others in the vicinity, are strongly affected by the subtropical Azores Current $(A C)$ diverging from the Gulf Stream, and by the Portugal Current (PC) as the southern branch of the North Atlantic Current (advecting freshly ventilated waters to the south) (Voelker et al., 2010; Rodrigues et al., 2011). According to Rodrigues et al. (2011), Pleistocene fluctuations of SST in the MD03-2699 record reflect the longitudinal migration of the Polar Front and subtropical water masses, modelling climatic conditions in warm and cold phases off the Iberian Peninsula. It seems to be an unlikely situation that the westerlies from this region influenced substantially and directly the climate in Poland. Today, the tropical maritime air mass from this region appears in Poland only sporadically throughout the year. However, at all sites analysed in this paper, surface waters are finally transported in various forms from the Gulf Stream and the North Atlantic Current (NAC). Hence, we think that rather general changes in this current system induced changes in the weather in Poland.

\section{UNCERTAINTIES IN CORRELATION OF MARINE AND TERRESTRIAL STAGE BOUNDARIES}

This problem has been best recognized for the Eemian Interglacial (cf. Tzedakis, 2003), but should be also valid for the earlier interglacials. A lag of the Eemian terrestrial boundaries with respect to the marine ones was determined. The age of the Eemian could be estimated by comparing the curve of sea surface temperature based on the benthic and planktic $\delta^{18} \mathrm{O}$ record in the deep-sea core MD95-2042 off south-west Portugal (Sánchez Goñi et al., 1999; Shackleton et al., 2002) and the arboreal pollen (AP) percentages from Bispingen in Germany (Müller, 1974b). Marine evidence suggested that interglacial conditions in the sea were initiated already at $132 \mathrm{ky} \mathrm{BP}$ and ter- 
minated at $115 \mathrm{ky}$, whereas the Eemian, recorded by the pollen diagram in the deep-sea core MD95-2042, was reported as lasting from $126.1 \mathrm{ka}$ to $109.7 \mathrm{ky}$ (cf. Shackleton et al., 2002).

This lag, however, is most distinct if comparing the temperatures based on benthic evidence. SST, determined based on planktic $\delta^{18} \mathrm{O}$ in the core MD95-2042, is much closer to terrestrial estimations. Certainly, the terrestrial interglacial could start earlier and terminate later in southern Europe. Eventual delay of initial interglacial conditions on land in this region could indicate high dependence of terrestrial vegetation on water circulation in the North Atlantic, and, especially, replacement of the NAC by cold Arctic currents prevailing during climate deterioration at the end of the interglacial. Such tight relation of marine and terrestrial conditions at the end of the interglacial was indicated by a sudden drop of SST, reflected by alkenone analysis of the core MD95-2042 at 113-111 ka. This cooling presumably appeared already at $\sim 115 \mathrm{ka}$ on the British Isles (Shackleton et al., 2002).

A high dependence of environmental conditions in northern continental Europe on the NAC was suggested for the Eemian and Early Weichselian (cf. Marks et al., 2016). At that time, eastward increasing continentality was typical for the Eemian and the following warm interstadials (Amersfoort, Brörup and Odderade), but westward increasing continentality during the intervening colder stadials (Herning, a cold phase between the Amersfoort and Brörup, Rederstall). An eastward decreasing trend of continentality in Europe during cold stadials could result from a remarkably less dynamic NAC and extensive sea-ice cover in the North Atlantic, favouring, among others, permafrost aggradation on the adjoining land.

\section{CONCLUSIONS}

In the light of the above considerations, the location of the Holsteinian and the Ferdynandovian in the stratigraphical framework of the Pleistocene is beyond dispute. They can be correlated with warm phases of MIS 11 (Holsteinian), and with the upper optimum of MIS 15 and a small part of MIS 14 (Ferdynandovian; Table 1).

It is justified to assume that the equivalent of MIS 13 is the Rhume Interglacial.

We give clear, credible answers to the question how long the terrestrial equivalents of the warm intervals of MIS 11 ( 33 ky), MIS 13 (57 ky) and part of MIS 15 and MIS14 (15 and 8 ky) are. In the case of MIS 13, the duration of the interglacial is unusual. The estimated, extremely long time span of the continental interglacial within MIS 13 makes it the longest one known from the Quaternary period.

Alkenone-based SST reconstruction $\left(\mathrm{U}_{37}^{\mathrm{k}^{\prime}}\right)$ is the most reliable method to investigate the more subtle climatic trends recorded in marine cores, whereas the results, based on the oxygen isotope record (benthic and planktonic foraminifera), allow for only partial modelling of climatic changes, especially those of higher magnitude.

Acknowledgements. We thank $\operatorname{Dr} A$. Voelker and the anonymous reviewer for their careful reading of our manuscript and very helpful comments and suggestions. Research project funded partly by the National Science Centre in Poland (decision No. DEC-2013/09/B/ST10/02040) and grant No. N 2016/21/B/ST10/03059.

\section{REFERENCES}

Amore, F.O., Flores, J.A., Voelker, A.H.L., Lebreiro, S.M., Palumbo, E., Sierro, F.J., 2012. A Middle Pleistocene Northeast Atlantic coccolithophore record: paleoclimatology and paleoproductivity aspects. Marine Micropaleontology, 90-91: $44-59$.

Berger, A., Crucifix, M., Hodell, D.A., Mangili, C., McManus, J.F., Otto-Bliesner, B., Pol, K., Raynaud, D., Skinner, L.C., Tzedakis, P.C., Wolff, E.W., Yin, Q.Z., Abe-Ouchi, A., Barbante, C., Brovkin, V., Cacho, I., Capron, E., Ferretti, P., Ganopolski, A., Grimalt, J.O., Hönisch, B., Kawamura, K., Landais, A., Margari, V., Martrat, B., Masson-Delmotte, V., Mokeddem, Z., Parrenin, F., Prokopenko, A.A., Rashid, H., Schulz, M., Vazquez Riveiros, N., 2016. Past Interglacials Working Group of PAGES (2016), Interglacials of the last 800,000 years. Reviews of Geophysics, 54: 162-219.

Binka, K., Nitychoruk, J., 1996. Geological and palaeobotanical setting of interglacial sediments at the Kaliłów site in southern Podlasie. Geological Quarterly, 40 (2): 269-282.

Bińka, K., Nitychoruk, J., 2011. Cyclicity in the Eemian climate? A case study of the Eemian site at Czaple, Eastern Poland. Review of Palaeobotany and Palynology, 164: 39-44.

Bińka, K., Nitychoruk, J., 2013. Lightning-caused and human-induced forest fires as evidenced by Pteridium spores in selected Quaternary records from Poland. Studia Quaternaria, 30: $29-40$.

Bińka, K., Cieśla, A., Łącka, B., Madeyska, T., Marciniak, B., Szeroczyńska, K., Więckowski, K., 1991. The development of Błędowo Lake (Central Poland) - a palaeoecological study. Studia Geologica Polonica, 100: 1-83.
Bittmann, F., Müller, H., 1996. The Kärlich Interglacial site and its correlation with the Bilshausen sequence. In: The Early Middle Pleistocene in Europe (ed. C. Turner): 187-193. A.A. Balkema, Rotterdam.

Candy, I., Schreve, C.D., Sherriff, J., Tye, J.G., 2014. Marine Isotope Stage 11: Palaeoclimates, palaeoenvironments and its role as an analogue for the current interglacial. Earth-Science Reviews, 128: 18-51.

de Abreu, L., Abrantes, F.F., Shackleton, N.J., Tzedakis, P.C., McManus, J.F., Oppo, D.W., Hall, M.A., 2005. Ocean climate variability in the eastern North Atlantic during interglacial marine isotope stage 11: a partial analogue for the Holocene? Paleoceanography, 20: 1-15.

Desprat, S., Sánchez Goñi, M.F., Turon, J.-L., McManus, J.F., Loutre, M.F., Duprat, J., Malaizé, B., Peyron, O., Peypouquet, J.-P., 2005. Is vegetation responsible for glacial inception during periods of muted insolation changes? Quaternary Science Reviews, 24: 1361-1374.

Diehl, M., Sirocko, F., 2008. Pollen record from Eifel maar. Supplement to: Diehl, M. and Sirocko, F. (2007): a new Holsteinian pollen record from the dry maar at Döttingen (Eifel). In: The Climate of Past Interglacials. Developments in Quaternary Science, 7 (eds. F. Sirocko, M. Claussen, T. Litt and M.F. Sánchez Goñi): 397-416. Elsevier, Amsterdam.

Gaudzinski, S., Bittmann, F., Boenigk, W., Frechen, M., van Kolschoten, T., 1996. Palaeoecology and archaeology of the Kärlich-Seeufer open-air site (Middle Pleistocene) in the Central Rhineland, Germany. Quaternary Research, 46: 319-334. 
Geyh, M.A., Müller, H., 2005. Numerical ${ }^{230} \mathrm{Th} / \mathrm{U}$ dating and a palynological review of the Holsteinian/Hoxnian Interglacial. Quaternary Science Reviews, 24: 1861-1872.

Geyh, M.A., Müller, H., 2007. Palynological and geochronological study of the Holsteinian/Hoxnian/Landos interglacial. Developments in Quaternary Sciences, 7: 387-396.

Gibbard, P.L., Boreham, S., Cohen, K.M., Moscariello, A., 2005. Global chronostratigraphical correlation table for the last 2.7 million years. Boreas, 34 (inclusion).

Herbert, T.D., 2003. Alkenone paleotemperature determiantion. Treatise on Geochemistry, 6: 391-432.

Imbrie, J., Shackleton, N.J., Pisias, N.G., Morley, J.J., Prell, W.L., Martinson, D.G., Hays, J.D., Maclntyre, A., Mix, A.C., 1984. The orbital theory of Pleistocene climate: support from a revised chronology of the marine $\delta^{18} \mathrm{O}$ record. In: Milankovitch and Climate (ed. A. Berger): 269-305, Part 1. Reidel, Hingham, Massachusetts.

Jouzel, J., Masson-Delmotte, V., Cattani, O., Dreyfus, G., Falourd, S., Hoffmann, G., Minster, B., Nouet, J., Barnola, J.M., Chappellaz, J., Fischer, H., Gallet, J.C., Johnsen, S., Leuenberger, M., Loulergue, L., Luethi, D., Oerter, H., Parrenin, F., Raisbeck, G., Raynaud, D., Schilt, A., Schwander, J., Selmo, E., Souchez, R., Spahni, R., Stauffer, B., Steffensen, J.P., Stenni, B., Stocker, T.F., Tison, J.L., Werner, M., Wolff, E.W., 2007. Orbital and millennial Antarctic climate variability over the past 800,000 years. Science, 317: 793-796.

Koutsodendris, A., Müller, U.C., Pross, J., Brauer, A., Kotthoff, U., Lotter, A.F., 2010. Vegetation dynamics and climate variability during the Holsteinian interglacial based on a pollen record from Dethlingen (northern Germany). Quaternary Science Reviews, 29: 3298-3307

Koutsodendris, A., Pross, J., Müller, U.C., Brauer, A., Fletcher, W.J., Kühl, N., Kirilva, E., Verhagen, T.M., Lucke, A., Lotter, A.F., 2012. A short-term climate oscillation during the Holsteinian interglacial (MIS 11c): an analogy to the $8.2 \mathrm{ka}$ climatic event? Global and Planetary Change, 92-93: 224-235.

Krupiński, K.M., 1995. Pollen stratigraphy and succession of vegetation during the Mazovian interglacial based on studies of sediments from Podlasie. Acta Geographica Lodziensia, 70: 1-200.

Kultti, S., Mikkola, K., Virtanenj, T., Timonen, M., Eronen, M., 2006. Past changes in the Scots pine forest line and climate in Finnish Lapland: a study based on megafossils, lake sediments, and GIS-based vegetation and climate data. The Holocene, 16: 381-391.

Kuneš, P., Odgaard, B.V., Gaillard, M.J., 2011. Soil phosphorus as a control of productivity and openness in temperate interglacial forest ecosystems. Journal of Biogeography, 38: 2150-2164.

Kühl, N., Gobet, E., 2010. Climatic evolution during the Middle Pleistocene warm period of Bilshausen, Germany, compared to the Holocene. Quaternary Science Reviews, 29: 3736-3749.

Lawrence, K.T., Herbert, T.D., Brown, C.D., Raymo, M.E., Haywood, A.M., 2009. High-amplitude variations in North Atlantic sea surface temperature during the early Pliocene warm period. Paleooceanography, 24: PA2218.

Lindner, L., Marks, L., Nita, M., 2013. Climatostratigraphy of interglacials in Poland: Middle and Upper Pleistocene lower boundaries from a Polish perspective. Quaternary International, 292: 113-123.

Lisiecki, L.E., Raymo, M.E., 2005. A Plio-Pleistocene stack of 57 globally-distributed benthic $\delta^{18} \mathrm{O}$ records. Paleoceanography, 20: 1-17, PA1003.

Litt, T., Behre, K.-E., Meyer, K.-D., Stephan, H.-J., Wansa, S., 2007. Stratigraphische Begriffe für das Quartär des northdeutschen Vereisungsgebites. Eiszeitalter und Gegenwart, 56: 7-65.

Luttig, G., Maarleveld, G.C., 1962. Über altpleistozäne Kiese in der Veluwe. Eiszeitalter u. Gegenwart, 13: 231-237.

Marks, L., Gałązka, D., Woronko, B., 2016. Climate, environment and stratigraphy of the last Pleistocene glacial stage in Poland. Quaternary International, 420: 259-271.

Martinson, D.G., Pisias, N.G., Hays, J.D., Imbrie, J., Moore, T.C. Jr, Shackleton, N.J., 1987. Age dating and the orbital theory of the ice ages: development of a high-resolution 0 to $300,000-$ -year chronostratigraphy. Quaternary Research, 27: 1-29.

Martrat, B., Grimalt, J.O., Shackleton, N.J., de Abreu, L., Hutterli, M.A., Stocker, T.F., 2007. Four climate cycles of recurring deep and surface water destabilizations on the Iberian margin. Science, 317: 502-507.

McManus, J.F., Oppo, D.W., Cullen, J.L., 1999. A 0.5 million year record of millennial-scale climate. Science, 283: 971-974.

Müller, H., 1965. Eine pollenanalytische Neubearbeitung des Interglazial-Profils von Bilshausen (Unter-Eichsfeld). Geologisches Jahrbuch, 83: 327-352.

Müller, H., 1974a. Pollenanalytische Untersuchungen und Jahresschichtenzählungen an der holstein-zeitlichen Kieselgur von Munster-Breloh. Geologisches Jahrbuch A, 21: 107-140.

Müller, H., 1974b. Pollenanalytische Untersuchungen und Jahresschichtenzählungen an der eem-zeitlichen Kieselgur von Bispingen/Luhe. Geologisches Jahrbuch A, 21: 149-169.

Müller, H., 1992. Climatic changes during and at the end of the interglacials of the Cromerian Complex. In: Start of a Glacial (eds. G.J. Kukla and E. Went): 51-69. NATO ASI Series I, 3. Springer, Heidelberg.

Naafs, B.D.A., Hefter, J., Ferretti, P., Stein, R., Haug, G.H., 2011. Sea surface temperatures did not control the first occurrence of Hudson Strait Heinrich Events during MIS 16. Paleoceanography, 26, PA4201.

Nitychoruk, J., 2000. Climate reconstruction from stable-isotope composition of the Mazovian Interglacial (Holsteinian) lake sediments in eastern Poland. Acta Geologica Polonica, 50: 247-294.

Nitychoruk, J., Bińka, K., Hoefs, J., Ruppert, H., Schneider, J., 2005. Climate reconstruction for the Holsteinian Interglacial in eastern Poland and its comparison with isotopic data from Marine Isotope Stage 11. Quaternary Science Reviews, 24: 631-644.

Oliveira, D., Desprat, S., Rodrigues, T., Naughton, F., Hodell, D., Trigo, R., Rufino, M., Lopes, C., Abrantes, F., Sánchez Goñi, F.M., 2016. The diversity of millennial-scale cooling events in southwestern Europe during MIS 11. Quaternary Research, 86: 373-387.

Oliveira. D., Sánchez Goñi, F.M., Naughton, F., Polanco-Martínez, J.M., Jimenez-Espejo, F.J., Joan, O., Grimalt, Martrat, B., Voelker, H.L.A., Trigo, R., Hodell, D., Abrantes, F., Desprat, S., 2017. Unexpected weak seasonal climate in the western Mediterranean region during MIS 31, a high-insolation forced interglacial. Quaternary Science Reviews, 161: 1-17.

Pelánková, B., Chytrý, M., 2009. Surface pollen-vegetation relationships in the forest-steppe, taiga and tundra landscapes of the Russian Altai Mountains. Review of Palaeobotany and Palynology, 157: 253-265.

Pidek, A., Poska, A., 2013. Pollen based quantitative climate reconstructions from the Middle Pleistocene sequences in Łuków and Zdany (E Poland): species and modern analogues based approach. Review of Palaeobotany and Palynology, 192: 65-78.

Preusser, F., Drescher-Schneider, R., Fiebig, M., Schlüchter, C., 2005. Reinterpretation of the Meikirch pollen record, Swiss Alpine Foreland, and implications for the Middle Pleistocene chronostratigraphy. Journal of Quaternary Science, 20: 607-620.

Railsback, L.B., Gibbard, P.L., Head, M.J., Voarintsoa, N.R.G., Toucanne, S., 2015. An optimized scheme of lettered marine isotope substages for the last 1.0 million years, and the climatostratigraphic nature of isotope stages and substages. Quaternary Science Reviews, 111: 94-106.

Reille, M., de Beaulieu, J.-L., Svobodova, H., Andrieu-Ponel, W., Goeury, C., 2000. Pollen analytical biostratigraphy of the last five climatic cycles from a long continental sequence from the Velay region (Massif Central, France). Journal of Quaternary Science, 15: 665-685.

Rodrigues, T., Voelker, A.H.L., Grimalt, J.O., Abrantes, F., Naughton, F., 2011. Iberian Margin sea surface temperature during MIS 15 to 9 (580-300 ka): glacial suborbital variability versus interglacial stability. Paleoceanography, 26: PA1204.

Sánchez Goñi, M.F., Eynaud, F., Turon, J.L., Shackleton, N.J., 1999. High resolution palynological record off the Iberian mar- 
gin: direct land-sea correlation for the Last Interglacial complex. Earth and Planetary Science Letters, 171: 123-137.

Sánchez Goñi, F.M., Rodrigues, T., Hodell, D., Polanco-Martíneza, J.M., Alonso-García, M., Hernández-Almeida, I., Desprat, S., Ferretti, P., 2016. Tropically-driven climate shifts in southwestern Europe during MIS19, allow eccentricity interglacial. Earth and Planetary Science Letters, 448, 81-93.

Shackleton, N.J., Chapman, M., Sánchez Goñi, M.F., Pailler, D., Lancelot, Y., 2002. The classic marine isotope substage 5e. Quaternary Research, 58: 14-16.

Silva, A., Palma, S., Moita, M.T., 2008. Coccolithophores in the upwelling waters of Portugal: four years of weekly distribution in Lisbon Bay. Chapter 2: 43-78. In: Coccolithophores in Coastal Waters: Lisbon Bay, Portugal (ed. A.M. Azinheira Duarte Silva). Doutoramento em Biologia. Especialidade em Ecologia.

Stein, R., Hefter, J., Grützner, A., Voelker, A., Naafs, B.D.A., 2009. Variability of surface water characteristics and Heinrich-like events in the Pleistocene mid-latitude North Atlantic Ocean: biomarker and XRD records from IODP Site U1313 (MIS 16-9). Paleoceanography, 24: 1-13.

Tzedakis, C., 2003. Timing and duration of Last Interglacial conditions in Europe: a chronicle of a changing chronology. Quaternary Science Reviews, 22: 763-768.
Tzedakis, P.C., Wolff, E.W., Skinner, L.C., Brovkin, V., Hodell, D.A., McManus, J.F., Raynaud, D., 2012. Can we predict the duration of an interglacial? Climate of the Past, 8: 1473-1485.

Turner, C., 1970. The Middle Pleistocene deposits at Marks Tey, Essex. Philosophical Transactions of the Royal Society B, 257: 373-440.

Urban, B., Thieme, H., Elsner, H., 1988. Biostratigraphie, quartärgeologische und urgeschichtliche Befunde aus den Tagebau "Schöningen", Ldkr. Helmstedt. Zeitschrift der Deutschen Geologischen Gesellschaft, 139: 123-154.

Urban, B., Lenhard, R., Mania, D., Albrecht, B., 1991. Mittelpleistozän im Tagebau Schöningen, Ldkr. Helmstedt. Zeitschrift der Deutschen Geologischen Gesellschaft, 142: 351-372.

Voelker, A.H.L., Rodrigues, T., Billups, K., Oppo, D., McManus, J., Stein, R., Hefter, J., Grimalt, J.O., 2010. Variations in mid-latitude North Atlantic surface water properties during the mid-Brunhes (MIS 9-14) and their implications for the thermohaline circulation. Climate of the Past, 6: 531-552.

Zagwijn, W., 1998. The Cromerian complex stage of the Netherlands and correlation with other areas in Europe. In: The Early Middle Pleistocene in Europe (ed. C. Turner): 145-172, Balkema, Rotterdam. 